\title{
REFLECTIONS ON FAMILY FIRM GOALS AND THE ASSESSMENT OF PERFORMANCE
}

\begin{abstract}
Assessments of family firm effectiveness depend critically on how goals and performance outputs are measured. Similarly, assessments of family firm efficiency depend critically on how performance outputs and resource inputs are measured. We illustrate this by showing that the assessment of performance is affected by how different family firm goal systems are specified. Gaining a better understanding of these fundamental concepts gives family business scholars the rare opportunity to set the rules of the game about how the performance of family firms, and other organizations that pursue the non-financial goals of a dominant stakeholder, should be assessed.
\end{abstract}

Keywords: goals; performance; family business; socioemotional wealth; non-financial benefits; effectiveness; efficiency 


\section{Reflections on Family Firm Goals and the Assessment of Performance}

\section{INTRODUCTION}

One of the most frequently studied topics in family business research is family firm performance (Mazzi, 2011; Wagner, Block, Miller, \& Schwens, 2015). Performance can be measured in terms of organizational efficiency, the relationship between outputs and inputs, or in terms of organizational effectiveness, the relationship between outputs and goals (Hofer \& Schendel, 1978). ${ }^{1}$ Most of the studies of family business performance conducted thus far focus on efficiency instead of effectiveness because they do not specify the goals to be achieved, the contexts within which the goals were to be achieved, and/or do not assess performance in terms of the extent to which the outcomes have achieved the goals.

Assessing performance as achievement of goals is important for both family and nonfamily firms, but it is even more critical for the family firms because of the multiplicity of goals they are explicitly or implicitly assumed to possess. For example, if a family has both financial and non-financial goals for the firm it owns, and one is achieved but the other is not, what is one to conclude about the firm's performance? If the family business research community is to reach a deeper understanding of family firm performance, there is a need for researchers to clarify their assumptions about the goals that family firms pursue and how outcomes can be compared with goals to assess performance. ${ }^{2}$ Therefore, the purpose of this article is to discuss the implications and obstacles associated with assessing performance in

\footnotetext{
${ }^{1}$ Goals can be defined in a variety of ways (Kotlar, De Massis, Wright \& Frattini, 2018). In this article we view goals as measurable milestones sought by firm owners and managers in the continual pursuit of organizational purpose. As such, goals should be (1) linked to organizational purpose, (2) have an index for measurement (e.g., return on investment), (3) include a target to be achieved, which can include both minimum and aspirational levels of achievement, and (4) specify a time frame over which the goal should be achieved (Hofer \& Schendel, 1978). We focus primarily on the index and target. We do not attempt to link goals with purpose or stipulate a specific time frame although we largely focus on long term goals and performance.

2 This problem exists in most of the studies that have focused on efficiency because these studies have generally only measured financial outputs. By contrast, non-financial outputs and non-financial goals are both usually treated as independent variables, and rarely treated as dependent variables. Furthermore, the distinctions in the literature between the two concepts is not always clear. This confusion is both unfortunate and curious since non-financial goals and outcomes are sometimes considered to dominate financial goals and outcomes in family firms (e.g., Gomez-Mejia, Haynes, Nunez-Nickel, Jacobson, \& Moyano-Fuentes, 2007).
} 
terms of effectiveness (goal achievement) in family firms. However, because efficiency is

more commonly measured and is also essential, we will digress where necessary to consider

the measurement of efficiency in family business studies. We also note that survival is

another indicator of firm performance but since it represents a minimum rather than

maximum condition we shall treat it as a constraint that must be satisfied for goal

achievement.

\section{THE MULTIPLICITY OF FAMILY FIRM GOAL SYSTEMS}

Both family and non-family firms pursue financial and non-financial goals. Financial goals

can be expressed in terms of Financial Value Creation (Value Creation hereafter), which we

define as revenues minus costs, including the cost of capital. ${ }^{3}$ Scholars in economics and

finance mainly deal with economic efficiency; but since they assume that regardless of time-

period, the goal of firms is to maximize firm financial value, which is the accumulation of

\footnotetext{
${ }^{3}$ Cost of capital is a complex concept dealt with more fully in books on financial economics such as Fama \& Miller (1972). For our purposes, we argue that covering the cost of capital, which is the cost of equity when there is no debt, is necessary for Value Creation in the economic or financial sense since if satisfactory returns on invested capital are not achieved, the suppliers of capital will eventually want to withdraw their capital and will definitely not be willing to supply additional capital. Thus, we define cost of capital simply as the rate of return required to induce continued or new investments in an enterprise (e.g., Lambert, Leuz, \& Verrecchia, 2007). By so doing, we subscribe to the theory of financial value where the cost of capital is set objectively by the capital market. The most important point in the financial theory of capital markets is that, although cost of capital is determined by the riskiness of the cash flows, it is not the total risk but the non-diversifiable systematic risk that is priced. It means that the total risk to which the controlling family is exposed does not have a simple direct relationship with the cost of capital for a family firm's cash flows, especially if the risk is highly diversifiable. It also means that if the capital market values only financial benefits while owners of the family firm value both financial and non-financial benefits, the price that the financial market would be willing to pay for family firms may differ from the price at which the controlling family would be willing to sell (See Zellweger, Kellermanns, Chrisman \& Chua, 2012). This does not, however, mean that the cost of capital, although determined by the capital market, is not affected by the presence of family firms. See Osakwe, Chua \& Chrisman (2011) and Chua \& Schnabel (1986) about how together, the controlling family's non-traded control block, asymmetric information due to penchant for privacy, and non-financial benefits affect cost of capital through the capital market's simultaneous equilibriums in pricing information and risk. Thus, determining the cost of capital for family firms in an economy requires knowledge about the mix of industries, asset sizes, and controlling blocks held by family firms within that economy and how much information the controlling families tend to withhold from the capital market. The extent to which global capital markets are integrated becomes an issue because it determines the scope of the economy that must be considered. Although these are important considerations, we do not attempt to deal with them further as they are beyond the scope of our article, the purpose of which is to examine firm goals and firm performance in terms of goal achievement. Finally, we acknowledge that family firm owners may not always be concerned about the cost of capital in the short-run. For further insights the reader should consult Adams, Manners, and Astrachan (2004), Astrachan and Jaskiewicz (2008), and Zellweger and Astrachan (2008).
} 
Value Creation over time, economic efficiency is essentially the equivalent to effectiveness. However, management scholars have long recognized that bounded rationality makes maximization impossible and firms frequently satisfice by setting acceptable targets for firm performance over a specific time period (Cyert \& March, 1963; Simon, 1947). Management scholars also recognize that all firms have non-financial goals presumed to yield nonfinancial benefits for stakeholders (Cyert \& March, 1963). Furthermore, there appears to be a consensus among family business scholars that family firms may also pursue goals that yield family-oriented non-financial benefits (FONFB). ${ }^{4}$ These goals are rarely, if ever, relevant for non-family firms but are considered of critical importance for family firms (Chrisman, Chua, Pearson \& Barnett, 2012; Kotlar \& De Massis, 2013).

There are many ways the goals pursued by family firms can be specified. Below are a few, far from collectively exhaustive, examples of the variations possible. We express these in symbolic form for more clarity and to make it easier to see the differences. Furthermore, to simplify the exposition, we shall ignore the non-financial goals and benefits that pertain to all firms so that we may focus on the interplay between Value Creation and FONFB, which is the crux of the differences between family and non-family firms as well as among heterogeneous family firms (Williams, Pieper, Kellermanns \& Astrachan, 2018; Kotlar, Signori, De Massis \& Vismara, 2017). ${ }^{5}$ Finally, we assume that the ultimate goal of family firm owners is to optimize their utility, but that they will usually have goal targets or minimums believed to yield a satisfactory level of utility over a specific period, as well as face resource constraints that limit goal achievement.

\footnotetext{
${ }^{4}$ Family-oriented non-financial benefits (FONFB) are of course closely related to the well-known concept of socioemotional wealth (SEW). We chose to focus on FONFB, however, because SEW is about stocks of affective endowments (Chua, Chrisman, \& De Massis, 2015). By contrast, we are focusing on the measurement of goals and outputs of both the financial and non-financial varieties. Goals and outputs deal, respectively, with the flows of desired and actual financial and non-financial benefits accruing to families through the formulation and implementation of firm strategies. Therefore, FONFB which captures flows rather than stocks, better encapsulates the ideas we wish to express in this article even though our discussion applies to SEW as well.

${ }^{5}$ For the purpose of exposition, we also ignore financial goals that generate private benefits for managers and/or owners but do not increase Value Creation.
} 


\section{Financial goal in terms of Value Creation ONLY}

GOAL: Optimize Total $U=U_{v}($ Value Creation $)$

\section{SUBJECT TO THE CONSTRAINTS:}

- Value Creation Goal Target $\geq \Delta \mathrm{V}^{*} \geq 0$

- $\operatorname{Rv}_{\mathrm{V}}($ Value Creation $) \leq$ Total resources available

Where $\mathrm{Uv}_{\mathrm{v}}($.$) is the utility function for Value Creation; \Delta \mathrm{V}^{*}$ is the minimum level of Value Creation or change in value acceptable to the firm, which must not be negative to ensure long-term firm survival; ${ }^{6}$ and $\mathrm{R}_{\mathrm{V}}($.$) is the resource utilization function for the$ Value Creation achieved.

With this goal system, the firm pursues only Value Creation with available resources acting as the constraint to goal achievement. Consequently, this is the goal system assumed to dominate among non-family firms, notwithstanding our simplification from excluding the non-financial goals and private benefits relevant to both family and non-family firms.

As noted above, a basic assumption in economics, especially financial economics, is that firms pursue only financial goals except when altruism is explicitly included. ${ }^{7} \mathrm{We}$ express the goal system in the form of a utility function to accommodate the possibility that the controlling family's welfare or sense of well-being from goal achievement will not increase linearly with Value Creation for reasons such as risk aversion. ${ }^{8}$ By using the term "optimize" instead of "maximize", we acknowledge bounded rationality. We also specify a minimum and aspirational level of goal achievement to reflect the fact that firms often

\footnotetext{
${ }^{6} \mathrm{We}$ acknowledge that, in the short run, a firm does not have to be creating value to survive. In fact, in the short run, a firm can survive with negative accounting (or economic) profit so long as it has positive cash flows, or even negative cash flows so long as it can secure additional equity or debt capital through financing to meet short-term cash flow needs. But, in the long run, access to financial capital, even family financial capital, will vanish if there is no value creation. On another point, note that although we conceptualize Value Creation based upon economic and financial theories, our exposition of goal systems, including both the goals and the constraints, apply equally when using accounting profits or even cash flows as measures of Value Creation. ${ }^{7}$ Although economists are beginning to recognize that this assumption is not valid, most of their empirical work continues to be based on this assumption, perhaps because non-financial goals and outcomes are so difficult to model and measure.

8 This is not the classical economics utility function based on stock but similar to the behavioral economics utility function such as the one used in prospect theory which is based on change or flow (e.g., Starmer, 2000). To measure utilities as a stock we would use financial value and socioemotional wealth (SEW) instead of Value Creation and FONFB.
} 
specify a performance target that, if not attained, will trigger a search for alternative strategies to achieve the goal (Cyert \& March, 1963). Note that the goal system modeled allows resources used to be less than resources available to accommodate slack. ${ }^{9}$ How resource constraints affect performance assessment will be discussed in the next section.

2. Business-first goal system:

GOAL: Optimize Total $\mathrm{U}=\mathrm{U}_{\mathrm{v}}($ Value Creation $)$

\section{SUBJECT TO THE CONSTRAINTS:}

- Value Creation Goal Target $\geq \Delta \mathrm{V}^{*} \geq 0$

- FONFB $>0$

- $\mathrm{R}_{\mathrm{V}}($ Value creation $) \leq$ Total resources available $-\mathrm{R}_{\mathrm{F}}(\mathrm{FONFB})$

Where $\mathrm{Uv}_{\mathrm{v}}($.$) and \mathrm{R}_{\mathrm{v}}($.$) are utility functions and resource utilization functions for Value$ Creation, respectively, as defined before; and $\mathrm{R}_{\mathrm{F}}($.$) is the resource utilization function for$ the FONFB achieved. As expressed, $\mathrm{R}_{\mathrm{F}}($.$) reduces the total resources available for Value$ Creation. Again, to ensure the long-term existence of the firm, $\Delta \mathrm{V}^{*}$ cannot be negative. Although FONFB is a constraint that does not contribute directly to Total $U$, it must be positive to ensure some minimum level of cooperation from family members needed to achieve any Value Creation.

The goal system for firms referred to as business-first family firms in the literature (e.g., Distelberg \& Sorenson, 2009) includes a financial goal with a family-oriented nonfinancial constraint. Although goal targets may fluctuate in the short term, over the long-term family firms with this goal system will need to generate a minimum level of FONFB such as family harmony and will expend resources to ensure this is achieved but do not consider it a goal and gain no direct utility from it. FONFB cannot be zero, however, because, without it, family harmony may suffer so much that Value Creation would be very difficult or even impossible to achieve. ${ }^{10}$ Without this constraint, the situation would devolve to the financial

\footnotetext{
${ }^{9}$ Firms have many different types of resources that are difficult to combine into one variable, including human, social, and financial capital; intangible and tangible resources; tacit and explicit knowledge, short and long-term assets, etc. This simplification is for representational and expositional convenience.

${ }^{10}$ Without a minimum level of family harmony, there will be, at least, disruption of the business. If the disharmony causes the family firm to split up, then split-up businesses will have less resources available for Value Creation and may even compete with each other intensifying the rivalry in the industry. And if the firm is sold to one or a few family members, repayment of the debt incurred to acquire ownership from the rest of the family could become the priority of the firm.
} 
goal only situation. In that case, the behavior of the business-first family firm would be no different from that of non-family firms, making their relative performance strictly comparable.

It is also important to note that if available resources are held constant, the Value Creation of business-first family firms is expected to be less than or equal to the Value Creation of non-family firms and family firms with only financial goals because a portion of the family firm's resources must be diverted toward satisfying the FONFB constraint. ${ }^{11}$ Finally, the specification implicitly assumes that the Value Creation goal and FONFB constraint are independent of each other, i.e., there is no complementary, substitutive, or conflicting effect on utility between them (Mazzelli, Kotlar, \& De Massis, 2018; Zellweger and Nason, 2008). Trade-offs in the pursuance of goals arise entirely from the resource constraint, i.e., resources devoted to FONFB will not be available for Value Creation, and vice versa.

\section{Family-first goal system:}

GOAL: Optimize Total $\mathrm{U}=\mathrm{U}_{\mathrm{F}}(\mathrm{FONFB})$

\section{SUBJECT TO THE CONSTRAINTS:}

- $\quad$ FONFB Goal Target $\geq \mathrm{F}>0$

- Value Creation $\geq 0$

- $\mathrm{R}_{\mathrm{F}}(\mathrm{FONFB}) \leq$ Total resource available $-\mathrm{R}_{\mathrm{V}}($ Value creation $)$

Where $U_{F}($.$) is the utility function for FONFB; F$ is the minimum level of FONFB acceptable to the firm; and $\mathrm{R}_{\mathrm{F}}($.$) and \mathrm{R}_{\mathrm{V}}($.$) are resource utilization functions as defined before.$

The goal system for "family-first" businesses (cf., Distelberg \& Sorenson, 2009) reverses the importance of Value Creation and FONFB. Achieving non-negative Value Creation is a constraint since the principals will not and cannot countenance destruction of

\footnotetext{
${ }^{11}$ However, if the resources have complementary effects, the resources allocated to achieving FONFB may contribute to Value Creation. So, the net effect may be partially, fully, or even more than fully offset.
} 
value in the long run. ${ }^{12}$ In some instances, however, family firms may be willing to sacrifice Value Creation in pursuance of FONFB, if satisfactory outcomes for both cannot be achieved (Gomez-Mejia, Haynes, Nunez-Nickel, Jacobson, \& Moyano-Fuentes, 2007). In that case, there would be no Value Creation constraint; but we presume this would hold for only a transitory adjustment period because consistent destruction of value over the long-term would put the business out of existence and make further FONFB impossible (cf., Chrisman \& Patel, 2012). ${ }^{13}$ As specified, our previous comments regarding independence and resource utilization as it pertains to Value Creation and FONFB in business-first firms applies for family-first firms as well.

3. Multiple substitute goals:

GOAL: Optimize Total $\mathrm{U}=\mathrm{Uv}_{\mathrm{V}}($ Value Creation $)+\mathrm{U}_{\mathrm{F}}(\mathrm{FONFB})$

\section{SUBJECT TO THE CONSTRAINTS:}

- Value Creation Goal Target $\geq \Delta \mathrm{V}^{*} \geq 0$

- $\quad$ FONFB Goal Target $\geq F>0$

- $\mathrm{R}_{\mathrm{V}}($ Value Creation $)+\mathrm{R}_{\mathrm{F}}(\mathrm{FONFB}) \leq$ Total resource available

Where $U_{V}(),. U_{F}(),. R_{V}($.$) and R_{F}($.$) are utility and resource utilization functions,$ respectively, as defined before. Again, to ensure the long-term existence of the firm, $\Delta \mathrm{V}^{*}$ cannot be negative while $\mathrm{F}$ must be positive to ensure some minimum level of cooperation from family members.

With this goal system, family firms have multiple substitutable goals to which the family attaches varying importance as expressed by the utility functions $U_{V}($.$) and U_{F}($.$) . The$ overall goal is to optimize the sum of the utilities received. ${ }^{14}$ The goals are substitutable

\footnotetext{
${ }^{12}$ We would like to remind the reader again that we are talking about the long run. In the long run, even if the incumbent generation does not find value creation important, later generation family shareholders, especially those not involved in managing the business, may consider seriously what return they could achieve in the capital markets with the funds they would get from selling their shares or the business.

${ }^{13}$ In terms of adjustments, we should note that failure to achieve the goal targets can result in a change in the strategy or even a change in the goals if there is no available strategic alternative that will achieve the goal targets (Cyert \& March, 1963).

${ }^{14}$ This specification has simplified the combination of utilities derived from goal achievement to a linear form. Adding nonlinearity would only complicate the mathematical expressions and the exposition. In addition, no conceptual generality is lost with this simplification.
} 
because the same value of Total $U$ can be obtained with different combinations of financial and non-financial goals and outcomes.

There can be two variations of this goal system. One with limited substitutability, which is the version specified above. In this version, substitutability ends at the minimum levels required: $\Delta \mathrm{V}^{*}$ for Value Creation and $\mathrm{F}$ for FONFB. This means that when the business fails to achieve the minimum level for one of the two goals, performance is unacceptable because the utility lost cannot be made up by the utilities gained from outcome achieved with respect to the other goal. In an unlimited substitutability version with respect to FONFB, for example, the business can fail in achieving its FONFB goal but the performance is acceptable so long as the deficiency in FONFB is made up by additional Value Creation. This second version may be represented by the following system:

GOAL: Optimize Total $\mathrm{U}=\mathrm{UV}_{\mathrm{V}}($ Value Creation $)+\mathrm{U}_{\mathrm{F}}(\mathrm{FONFB})$

\section{SUBJECT TO THE CONSTRAINTS:}

- Value Creation Goal Target $\geq 0$

- $\mathrm{R}_{\mathrm{V}}($ Value Creation $)+\mathrm{R}_{\mathrm{F}}(\mathrm{FONFB}) \leq$ Total resource available

In this version, the only specification for the goal target would be the need to achieve a nonnegative level of Value Creation. Thus, the loss of utility even when FONFB is negative can be made up for an indefinite period by utility gains from higher Value Creation, whereas for reasons of long-term survival, Value Creation cannot be negative for more than a limited period, the length of which depends on the family firm's resources. The difference between this and the Financial Goal Only system is that the latter ignores FONFB and, thus, less resources would have to be allocated to pursuing FONFB. A difference between this goal system and the Business-First or Family-First goal systems is that both Value Creation and FONFB contribute to the Total $U$ in the former while only Value Creation or FONFB does that in the latter two. 
4. Multiple positively complementary goals:

GOAL: Optimize Total $\mathrm{U}=\mathrm{U}_{\mathrm{V}}($ Value Creation $)+\mathrm{U}_{\mathrm{F}}(\mathrm{FONFB})$

$+\mathrm{UVF}_{\mathrm{VF}}($ Value Creation * FONFB)

SUBJECT TO THE CONSTRAINTS:

- Value creation Goal Target $\geq \Delta \mathrm{V}^{*} \geq 0$

- FONFB Goal Target $\geq F>0$

- $\mathrm{R}_{\mathrm{V}}($ Value creation $)+\mathrm{R}_{\mathrm{F}}(\mathrm{FONFB}) \leq$ Total resource available

Where $\mathrm{U}_{\mathrm{V}}(),. \mathrm{U}_{\mathrm{F}}(),. \mathrm{R}_{\mathrm{V}}($.$) , and \mathrm{R}_{\mathrm{F}}($.$) are utility functions and resource utilization functions,$ respectively, as defined before. $\mathrm{U}_{\mathrm{VF}}($.$) is the utility function for the complementarity$ between Value Creation and FONFB.

By two complementary goals we mean that achieving both goals yields a higher utility than the sum of the utilities from achieving the two goals if the goals were merely substitutable. Mathematically, the difference between this goal specification and the one for substitutable goals consists of the utility derived from the multiplicative interaction term which will be positive if both are greater than zero and will be zero if one or both are zero. This specification requires that the complementary portion of the utility function be scaled such that when Value Creation*FONFB is zero, that portion is zero.

The above goal system is the simplest way to represent positive goal complementarity. The actual goal system of a family firm is likely to be more complex than this when FONFB has multiple components. For example, there may be complementarity among some FONFB components (Chua, Chrisman \& De Massis, 2015). To accommodate that, the goal system specification would include multiplicative terms for the complementary FONFB components, such as FONFB1*FONFB2. ${ }^{15}$

\footnotetext{
${ }^{15}$ A more complicated specification than the mere inclusion of a multiplicative term is needed to allow for negative values of Value Creation and/or FONFB. However, including these complications would not add to the basic understanding of goal complementarity. Furthermore, this symbolic specification cannot allow for simultaneous negative values of Value Creation and FONFB because it would imply that, contrary to intuition, negative values for both Value Creation and FONFB would yield a higher utility because the product of two negative numbers is positive. Finally, although negative Value Creation or FONFB outcomes do occur, we assume that family owners would not set out to destroy value or NONFBs as reflected in the non-negativity constraints for both benefits.
} 
Like the situation where goals are substitutable, the presence of complementary goals suggests that family firms will not necessarily suffer from a performance disadvantage in terms of Total U vis-à-vis non-family firms just because it sacrifices Value Creation to pursue FONFB. In exchange for the utility lost from lower Value Creation, the family would receive an increase in utility from the higher FONFB. What makes the complementary goal situation different is that the family will receive additional utility from the complementarity effect. The net effect will, of course, depend on the extent to which goal complementarity exists and the trade-off between the utilities associated with Value Creation and FONFB.

An interesting and unique feature of goal complementarity is that the total resources needed by a family firm to achieve the same level of Total $U$ are lower than what it takes in all the previously discussed goal systems because the family will derive utility not only from the achievement of Value Creation and FONFB, by themselves, but also from the utility gained through the complementarity of the two. This is an important consideration because it implies that to the extent that goals are complementary, the resources needed to achieve a given level of Total $U$ will be lower than would otherwise be the case if goals are not complementary. Likewise, to the extent that goals are complementary, a higher level of Total U can be achieved with a given level of resources than when goals are not complementary. Thus, if resources are held constant, family firms with complementary Value Creation and FONFB goals should have the potential to achieve higher levels of Total $U$ than either nonfamily firms or other family firms with different goal systems.

As we mentioned at the beginning of the section, the above list includes just a small sample of possible family firm goal systems. We are confident that readers can imagine many variations on the ones that we listed. For example, we have specified systems where goals are 
substitutable or complementary but not systems where goals are conflicting. ${ }^{16}$ Systems with conflicting goals are essentially the inverse of systems with complementary goals. Thus, for example, when two FONFB goals are in conflict, the achievement of FONFB1 goal will diminish the utility gained from achieving the FONFB2 goal and vice-versa.

\section{IMPLICATIONS FOR FAMILY FIRM PERFORMANCE ASSESSMENT}

From the above discussion it should be obvious that how the effectiveness of family firms is assessed will depend critically on how their goals are specified. Once family business scholars admit explicitly that family firms have non-financial goals, then no study about the overall performance of family firms in terms of either efficiency or effectiveness is possible without measuring FONFB. Therefore, family business scholars simply cannot ignore FONFB. Of course, one can always say that the study is only about financial performance. But that means the researcher must either assume (a) family firms have only financial goals; or (b) non-financial goals and performance can be treated as independent variables that are relevant only in their impact on financial performance. In fact, most performance studies in the literature, rather than treat Value Creation and FONFB as parts of a system of goals and outcomes that together determine the effectiveness and efficiency of family firms, have made one of those assumptions; we are aware of few studies that use non-financial performance as a dependent variable separately or in combination with financial performance. The studies by Basco and Rodriguez (2011) and Basco (2013) are among the few exceptions.

We, however, are not arguing that using non-financial goals as independent variables is inappropriate even when the research is focused exclusively on financial outcomes; what concerns us is the lack of studies that measure non-financial performance and the propensity in the literature to confuse non-financial goals and outcomes, as well as treat both exclusively

\footnotetext{
${ }^{16}$ A conflict in goals is different from a conflict arising from limited resources. Technically, the former would be reflected in the objective function while the latter would arise from the resource constraint.
} 
as independent variables. This criticism, along with the others discussed in the literature (e.g., Chua et al., 2015; Miller \& Le Breton-Miller, 2014; Schulze \& Kellermanns, 2015) also applies to studies using socioemotional wealth (SEW), which is typically conceptualized as a stock or accumulation of affective and social FONFB but often treated (but rarely directly measured) more like a goal that influences behavior (e.g., Chrisman \& Patel, 2012).

Scholars are interested in family firm performance for the ultimate purpose of improving the performance of the economy and the well-being of the owning family. Comparing family and non-family firms and comparing different family firms make it easier to identify the causes of performance differences. In both situations, before doing the comparison, scholars must first be able to assess the performance of a single firm. This involves conceptual and measurement problems that are discussed below. ${ }^{17}$

Before discussing the problems of measuring non-financial goals and outcomes, it is important to deal with the problem of measuring resources allocated toward pursuing financial and non-financial benefits, which our discussion has so far ignored. First, take the simplest goal system that admits family firms' pursuance of FONFB - the business-first situation. Non-family firms will be pursuing Value Creation exclusively while family firms will be pursuing Value Creation as well as attempting to maintain a minimum acceptable level of FONFB. Even when family and non-family firms have the same amount of total resources, the family firm will allocate some resources to pursue FONFB. Conceptually, even when performance only in terms of Value Creation is compared, it is the value created plus the counterfactual of how much more value family firms would have created, if resources had not been allocated to pursuing FONFB, that should be compared with the Value Creation achieved by non-family firms. In other words, to get an unbiased estimate of the relative

\footnotetext{
${ }^{17}$ To avoid dealing with principal-principal agency problems which may be more serious in family firms, our discussion may be seen as one dealing only with firms that are $100 \%$ family owned.
} 
performance of family firms in terms of Value Creation, it would be necessary to consider the amount of resources allocated to achieving FONFB goals before making the comparison.

When ratio measures of efficiency (outputs/inputs) are used, this means that the denominator should ideally be adjusted downward to account for resources used to pursue FONFB; otherwise, the denominator would be overestimated.

In a cross-sectional comparison of Value Creation using ratio measures of effectiveness (outputs/goals), the purpose is to assess the impact of different levels and types of outcomes in achieving the family firm's goals. ${ }^{18}$ Here, there would not be a need to adjust for the resources allocated to pursue FONFB because the denominator for business-first family firms (or, for that matter, any type of family firm) is based on goals not resource allocations; in fact, any adjustment would invalidate such assessment. This would avoid the need to deal with a counterfactual. However, the actual Value Creation (the numerator) achieved would still be affected by any existing FONFB constraint.

For more complicated family firm goal systems such as when Value Creation and FONFB are substitutes, a firm with lower Value Creation may have derived higher FONFB from the business; in other words, the firm with lower Value Creation may have derived a higher Total $\mathrm{U}$ when the utility derived from Value Creation and the utility derived from FONFB are combined. In this case, the measure of outputs, (but not inputs) in the case of assessments of efficiency, and the measure of outputs and goals in the case of assessments of effectiveness, would need to consider FONFB. Naturally, the same logic regarding performance assessments when Value Creation and FONFB are substitutes also applies to

\footnotetext{
18 This discussion concerns itself only with measuring performance. It does not imply that resources are unimportant in achieving family firm goals. Indeed, the literature indicates that family firms may suffer from disadvantages in terms of acquiring human resources (Chua, Chrisman \& Bergiel, 2009; Colombo et al., 2014) and have both advantages and disadvantages in acquiring financial resources (Anderson, Mansi \& Reeb, 2003, Wu, Chua, \& Chrisman, 2007; Chua, Chrisman, Kellermanns, \& Wu, 2011).
} 
situations where Value Creation and FONFB are complementary or conflicting; only the implications for performance would differ. ${ }^{19}$

This means that family business scholars who believe that non-financial goal achievement and FONFB should be figured into assessments of family firm performance should view the literature comparing the financial performance of family and non-family firms with caution. Unless one takes the stand that family firms should not allocate the resources they own to pursue FONFB, or that FONFB should not be measured as a component of performance, such studies will inevitably yield biased conclusions about the relative performance of family and non-family firms and of different types of family firms. ${ }^{20}$

Some progress has been made in the conceptualization and measurement of FONFB, particularly with regard to the related concept of SEW (e.g., Berrone, Cruz, Gomez-Mejia, 2012; Filser et al., 2018; Williams et al., 2018). For example, Debicki, Kellermanns, Pearson, and Spencer (2016) have validated a socioemotional wealth importance $\left(\mathrm{SEW}_{\mathrm{i}}\right)$ scale that specifically acknowledges SEW as a goal; whereas Hauck, Suess-Reyes, Beck, Prügl, and Frank (2016) have validated a scale that seeks to measure SEW as an accumulation of affective benefits. Nevertheless, there is still no clear consensus about what the relevant

\footnotetext{
${ }^{19}$ When financial and non-financial goals are substitutable, complementary, or conflicting, no adjustment in the total amounts of inputs would be necessary since all resources are used to achieve the mixture of financial and non-financial goals of the firm. Therefore, using ratio measures of efficiency would only require adjustments to reflect FONFB in the numerator.

${ }^{20}$ Economists might insist that for reasons of economic welfare all firms should adhere to and be evaluated by utility functions that maximize Value Creation only. But such a position seems to us to be the antithesis of democracy built on foundations of individual liberty and property rights. Put differently, if controlling families derive utility from pursuing FONFB goals, who has the right to say that is wrong? Moreover, if we are to improve family firm performance, should we not consider the goals family owners are trying to achieve? It should be noted that some economists have started to consider non-financial outcomes such as happiness as a valid measure of resource-use productivity (e.g., Frey \& Stutzer, 2002), reviving, in effect, the earliest conceptualizations of utility (See Stigler, 1950). Indeed, the 2017 Nobel Prize in Economics was awarded to Richard Thaler for his work showing that psychology influences decision making and that the goals of human decision makers consist of much more than purely financial wealth maximization. Interestingly, in his award citation, the prize committee focused on self-control agency problems concerning inner conflicts with oneself that arise when a decision maker's preferences are influenced by multiple and conflicting financial and nonfinancial goals at the same point in time (Thaler \& Shefrin, 1981). This idea is central to the study of family firm behavior and performance given the prevalence of inner conflicts between financial and non-financial goals among family business owners (De Massis, Kotlar, Mazzola, Minola \& Sciascia, 2017).
} 
family-oriented non-financial goals are or how FONFB should be measured. Even if it was assumed that we know what the FONFB are, how to measure them, and the resources that must be allocated to produce them, there are still differences in how family firm performance should be assessed in accordance with different goal systems such as those discussed above. In other words, we need an approach that is powerful enough to accommodate differences in the goals and associated outcomes of family firms in comparison both to non-family firms and to each other.

The problem of different goal systems is further complicated by the fact that Value Creation is usually measured in monetary terms using profit, Tobin's Q, or one of the various financial performance ratios, whereas how to measure FONFB is currently much less clear, despite the recent advancements in the literature mentioned above. Moreover, assuming we could measure FONFB, the way in which that measure could be reconciled with the typical measures of Value Creation is neither clear nor easy. The most obvious solutions on how to derive a composite measure of these disparate concepts are to convert both into utilities or to convert FONFB into a monetary equivalent.

Although at first glance, taking either approach will encounter difficult-to-surmount obstacles, the easiest way to convert goals and outcomes to something that approaches utilities is to measure the importance attached to different goals and the satisfaction attached to their achievement. Unfortunately, this approach must be used with great care for two reasons. First, the common approach of multiplying importance and satisfaction hides relevant distinctions. Thus, mathematically, the product of high values of importance multiplied by low values of satisfaction can equal the product of low values of importance multiplied by high values of satisfaction. Second, neither importance nor satisfaction actually measures the goal target. This means that to ensure the scales are comparable across firms, the levels of the goal target must be measured, either absolutely or in relation to some 
benchmark or threshold (e.g., some level of average family harmony or family member commitment). If this can be done, it might be possible to calibrate differing levels and types of goal importance and satisfaction with goal achievement across firms.

In terms of converting FONFB to a monetary value, Zellweger, Kellermanns, Chrisman, and Chua (2012) have already shown that family business owners appear to attach monetary equivalent value to SEW. ${ }^{21}$ They show that the monetary price at which family business owners would be willing to sell their family firms to a family successor, when presumably the family would retain the financial value and the stock of SEW, is lower than the price at which they would be willing to sell their family firms to outsiders, when presumably all SEW would be lost and only financial value realized. This means that the difference between the two might be interpreted as the monetary value of SEW. Thus, measuring the monetary value of SEW or the stock of FONFB might indeed be possible.

In general, so long as we have an appropriate proxy for SEW or know how to measure it, comparing the combined financial and non-financial performances of family firms vis-àvis non-family firms or among themselves may be done using a two-step regression procedure. The first step is to determine how much SEW contributes to the combined financial value and stock of non-financial benefits created by the business. This result may then be used to construct effectiveness or efficiency measures for comparing the performance among family firms and between family firms and non-family firms.

The first step has already been demonstrated by Zellweger et al. (2012). With a sample of family firms, we would regress the price that the family would demand if the business is to be sold to non-family investors (when presumably all SEW associated with the business would be lost to the family and, as a result, the family would demand the monetary

\footnotetext{
${ }^{21}$ Although there is no conclusive evidence that SEW includes all FONFB, we use SEW to represent the stock of non-financial benefits available to family firms and continue our representation of FONFB as a flow. In this sense, SEW may be seen as the accumulation of FONFB.
} 
equivalent payment for that loss) against SEW as the independent variable and other determinants of firm value as control variables. ${ }^{22}$ The coefficient obtained for the SEW term would be a consensus measure of the monetary equivalent of a unit of SEW. Then, so long as we know how to measure the SEW of a business, the SEW for an individual firm multiplied by this coefficient would give us a consensus measure of what the firm's SEW contributes to the combined financial value and non-financial benefits created by the business, stated in monetary terms.

The monetary equivalent value that each family would attach to FONFB and SEW should be different and likely idiosyncratic, which the consensus monetary equivalent value obtained using this approach is obviously not. Instead, the monetary equivalent value for SEW estimated using this approach would reflect the consensus demand price in the "market for family businesses" for the combined financial and non-financial value if the business was sold to another family that could preserve for themselves, without loss, the SEW (i.e., accumulated stock of FONFB) by the selling family. ${ }^{23}$ But this may not be a crucial problem because conclusions flowing from the comparison of performances are about averages anyway and despite its flaws this approach represents a place to start.

In a cross-sectional comparison of performance, we would then construct the total financial value and SEW created by a family firm (flows) in monetary terms over the period examined. This Total Value would be the sum from adding the monetary equivalent value of the SEW to the purely financial value of the firm. The comparison of performance between family firms and non-family firms or among family firms would then be done through a second-step regression model with the Total Value as the dependent variable and either a

\footnotetext{
${ }^{22}$ Zellweger et al. used past, present, and future control to measure SEW. Other measures are possible but whichever is chosen the valuation by the family will be subjective. Its cardinal reliability must be examined rigorously first if this approach is to be used. It would likely be influenced by the willingness to pay and willingness to accept concepts pointed out by Zellweger et al. (2012).

${ }^{23}$ How much this is and whether families can get it when they sell their businesses is an important and interesting topic for research.
} 
binary family involvement variable or a variable combining measures of family involvement and family essence as the independent variable. The control variables would be other drivers of financial value, assuming that there are no other sources of non-financial benefits than FONFB. ${ }^{24}$

\section{CONCLUSIONS}

If we were pessimistic, we would consider surrendering in the face of the difficulties outlined above. We, however, believe that family business scholars should be cautiously optimistic and even enthusiastic because what we have outlined helps conceptualize the problems we face in more concrete terms and provides some initial directions for how the field can potentially establish a new game in family business performance research. Family business scholars have the rare opportunity to control the academic discourse about family firm performance by setting the rules of the game with respect to measuring and comparing family firm efficiency and effectiveness in terms of both financial and non-financial goals and outcomes.

Family business studies as a separate field has been legitimized through research that, despite its limitations, has shown that family firm behavior is different from that of nonfamily firms (e.g., Chrisman \& Patel, 2012; Gomez-Mejia et al., 2007). While further accumulation of evidence is still important, family business researchers need to dig deeper into the motivations of such distinctive behavior (e.g., De Massis et al., 2014) if they are serious about understanding family firms and developing a theory of the family firm. Achievement of FONFB and its aggregation as SEW is generally believed to be one of these

\footnotetext{
${ }^{24}$ Again, this ignores the non-financial and private benefit goals shared by owners and managers of family and non-family firms. The approach may also be used to study differences between family and non-family firms or among family firms in terms of the performance consequences of a change in behavior, a decision, or an action. However, this would require us to measure the changes in FONFB by comparing the FONFB before and after. The first step would be the same. But continuing the above example, in the second step of the regression analysis, the dependent variable would have to be the changes in the efficiency or effectiveness ratios for the sample firms.
} 
strong and unique sources of motivation of family firms. Understanding the nature and measurement of these goals and outcomes will benefit not just the field of family business studies, but also other research areas such as stakeholder theory, social entrepreneurship, and any other area where one or more dominant stakeholders, with non-financial goals oriented toward their own interests, are encountered.

To use a cliché, a thousand-mile journey starts with the first step, which is to identify the FONFB. As noted above, recent studies by Debicki et al. (2016) and Hauck et al. (2016) show promising directions and approaches to do this since the scales they developed will help measure SEW goals and accumulated outcomes, respectively. However, we recommend that, at this stage of our knowledge about FONFB, the data collected should be as broad and inclusive as possible and not be limited to those proposed in the SEW literature. Focus groups, clinical experiments, interviews with family firm stakeholders, and surveys should be used to help us determine the comprehensiveness of our list of FONFB and whether the components of SEW proposed in the literature include all FONFB. After that, the next step would be to examine the cardinality of the scales developed - can the scales be used to measure changes in the stock of FONFB singly or in the catch-all form of SEW? This is because we need to measure the desired flows or changes in the stock of FONFB to capture FONFB goals, whereas we need to measure the actual flows or changes in stocks to measure FONFB outcomes and output. When we, as a community, have done that, we will finally be ready to truly and truthfully discuss and measure family firm performance in its totality. 


\section{REFERENCES}

Adams, A. F., Manners, G. E., Astrachan, J. H., \& Mazzola, P. (2004). The importance of integrated goal setting: The application of cost-of-capital concepts to private firms. Family Business Review, 17(4), 287-302.

Anderson, R. C., Mansi, S. A., \& Reeb, D. M. (2003). Founding family ownership and the agency cost of debt. Journal of Financial Economics, 68(2), 263-285.

Astrachan, J. H., \& Jaskiewicz, P. (2008). Emotional returns and emotional costs in privately held family businesses: Advancing traditional business valuation. Family Business Review, 21(2), 139-149.

Basco, R. (2013). The family's effect on family firm performance: A model testing the demographic and essence approaches. Journal of Family Business Strategy, 4(1), 42-66.

Basco, R., \& Rodríguez, M. J. P. (2011). Ideal types of family business management: Horizontal fit between family and business decisions and the relationship with family business performance. Journal of Family Business Strategy, 2(3), 151-165.

Berrone, P., Cruz, C., Gomez-Mejia, L. R. (2012). Socioemotional wealth in family firms: Theoretical dimensions, assessment approaches, and agenda for future research. Family Business Review, 25(3), 258-279.

Chrisman, J.J., Chua, J.H., De Massis, A., Frattini, F., \& Wright, M. (2015). The ability and willingness paradox in family firm innovation. Journal of Product Innovation Management, 32(3), 310-318.

Chrisman, J.J., Chua, J.H., Pearson, A.W., \& Barnett, T. (2012). Family involvement, family influence, and family-centered non-economic goals in small firms. Entrepreneurship Theory and Practice, 36(2), 267-293.

Chrisman, J. J., \& Patel, P. C. (2012). Variations in R\&D investments of family and nonfamily firms: Behavioral agency and myopic loss aversion perspectives. Academy of Management Journal, 55(4), 976-997.

Chua, J.H., Chrisman, J.J., Kellermanns, F., \& Wu, Z. (2011). Family involvement and new venture financing. Journal of Business Venturing, 26(4), 472-488.

Chua, J. H., Chrisman, J. J., \& Bergiel, E. B. (2009). An agency theoretic analysis of the professionalized family firm. Entrepreneurship Theory and Practice, 33(2), 355-372.

Chua, J.H., Chrisman, J.J., \& De Massis, A. (2015). A closer look at socioemotional wealth: Its flows, stocks, and prospects for moving forward. Entrepreneurship Theory and Practice, 39(2), 173-182.

Chua, J.H., \& Schnabel, J.A. (1986). Nonpecuniary benefits and asset market equilibrium. Financial Review, 21(2), 185-190.

Colombo, M.G., De Massis, A., Piva, E., Rossi-Lamastra, C., \& Wright, M. (2014). Sales and employment changes in entrepreneurial ventures with family ownership: Empirical evidence from high-tech industries. Journal of Small Business Management, 52(2), 226245.

Cyert, R. M., \& March, J. G. (1963). A behavioral theory of the firm. Englewood Cliffs, NJ: Prentice-Hall.

De Massis, A., Kotlar, J., Chua, J.H., \& Chrisman, J.J. (2014). Ability and willingness as sufficiency conditions for family-oriented particularistic behavior: Implications for theory and empirical studies. Journal of Small Business Management, 52(2), 344-364.

De Massis, A., Kotlar, J., Mazzola, P., Minola, T., \& Sciascia, S. (2017). Conflicting selves: Family owners' multiple goals and self-control agency problems in private firms. Entrepreneurship Theory and Practice, 42(4), In press. DOI: 10.1111/etap.12257. 
Debicki, B. J., Kellermanns, F. W., Chrisman, J. J., Pearson, A. W., \& Spencer, B. A. (2016). Development of a socioemotional wealth importance (SEWi) scale for family firm research. Journal of Family Business Strategy, 7(1), 47-57.

Distelberg, B., \& Sorenson, R. L. (2009). Updating systems concepts in family businesses A focus on values, resource flows, and adaptability. Family Business Review, 22(1), 65-81.

Fama, E.G., \& Miller, M.H. (1972). The Theory of Finance. Hinsdale, IL: Dryden Press.

Filser, M., De Massis, A., Gast, J., Kraus, S., \& Niemand, T. (2018). Tracing the roots of innovativeness in family SMEs: The effect of family functionality and socioemotional wealth. Journal of Product Innovation Management. In press. DOI: 10.1111/jpim.12433.

Frey, B.S., \& Stutzer, A. (2002). What can economists learn from happiness research? Journal of Economic Literature, 40(2): 402-435.

Gomez-Mejia, L.R., Haynes, K.T., Nunez-Nickel, M., Jacobson, K.J.L., \& Moyano-Fuentes, J. (2007). Socioemotional wealth and business risks in family-controlled firms: Evidence from Spanish olive oil mills. Administrative Science Quarterly, 52(1), 106-137.

Hauck, J., Suess-Reyes, J., Beck, S., Prügl, R., \& Frank, H. (2016). Measuring socioemotional wealth in family-owned and-managed firms: A validation and short form of the FIBER Scale. Journal of Family Business Strategy, 7(3), 133-148.

Hofer, C.W. \& Schendel, D. (1978). Strategy Formulation: Analytical Concepts. St. Paul, MN: West Publishing.

Kotlar J. \& De Massis A. (2013). Goal setting in family firms: Goal diversity, social interactions, and collective commitment to family-centered goals. Entrepreneurship Theory and Practice, 37(6), 1263-1288.

Kotlar, J., De Massis, A., Wright, M., \& Frattini, F. (2018). Organizational goals: Antecedents, formation processes, and implications for firm behavior and performance. International Journal of Management Reviews, 20(S1), S3-S18.

Kotlar, J., Signori, A., De Massis, A., \& Vismara, S. (2017). Financial wealth, socioemotional wealth and IPO underpricing in family firms: A two-stage gamble model. Academy of Management Journal. In press. DOI: 10.5465/amj.2016.0256.

Lambert, R., Leuz, C., \& Verrecchia, R.E. (2007). Accounting information, disclosure, and the cost of capital. Journal of Accounting Research, 45(2), 385-420.

Mazzelli, A., Kotlar,J., \& De Massis, A. (2018). Blending in while standing out: Selective conformity and new product introduction in family firms. Entrepreneurship Theory and Practice. In press. DOI: 10.1177/1042258717748651.

Mazzi, C. (2011). Family business and financial performance: Current state of knowledge and future research challenges. Journal of Family Business Strategy, 2(3), 166181.Miller, D., \& Le Breton-Miller, I. (2014). Deconstructing socioemotional wealth. Entrepreneurship Theory and Practice, 38(4), 713-720.

Osakwe, C.J., Chua, J.H., and Chrisman, J.J. (2011). Asset market equilibrium with significant family ownership. Meeting of the Midwest Finance Association.

Schulze, W. S., \& Kellermanns, F. W. (2015). Reifying socioemotional wealth. Entrepreneurship Theory and Practice, 39(3), 447-459

Simon, H.A. (1947). Administrative Behavior. New York: MacMillan.

Starmer, C. (2000). Developments in non-expected utility theory: The hunt for a descriptive theory of choice under risk. Journal of Economic Literature, 38(2), 332-382.

Stigler, G.J. (1950). The development of utility theory. I. Journal of Political Economy, 58(4), 307-327.

Thaler, R. H. \& Shefrin, H. M. (1981). An economic theory of self-control. Journal of Political Economy, 89, 392-406. 
Wagner, D., Block, J. H., Miller, D., Schwens, C., \& Xi, G. (2015). A meta-analysis of the financial performance of family firms: Another attempt. Journal of Family Business Strategy, 6(1), 3-13.

Williams Jr., R.I., Pieper, T.M., Kellermanns, F.W. \& Astrachan, J.H. (2018). Family firm goals and their effects on strategy, family and organization behavior: A review and research agenda. International Journal of Management Reviews, 20(S1), S63-S82.

Wu, Z., Chua, J.H., \& Chrisman, J.J. (2007). Effects of family ownership and management in small business equity financing. Journal of Business Venturing, 22(6), 875-895.

Zellweger, T.M. \& Astrachan, J.H. (2008). On the emotional value of owning a firm. Family Business Review, 21(4), 347-363.

Zellweger, T. M., Kellermanns, F. W., Chrisman, J. J., \& Chua, J. H. (2012). Family control and family firm valuation by family CEOs: The importance of intentions for transgenerational control. Organization Science, 23(3), 851-868.

Zellweger, T. M., \& Nason, R. S. (2008). A stakeholder perspective on family firm performance. Family Business Review, 21(3), 203-216. 